\title{
Fermentation activity of dung at use of biologically active specimens
}

\author{
Moroz V. ${ }^{1}$, Kaplinskyi V. ${ }^{2}$, Vorobel M. ${ }^{3}$, Garmadiy $0 .{ }^{4}$ \\ Institute of agriculture of Carpathian region of NAAS, Grushevskyi Str., 5, Obroshyne, Pustomytivskyi region, \\ Lviv oblast, 81115, Ukraine; e-mail: 1 veramoroz0@gmail.com, 2 vasyl.kaplinskiy@gmail.com, 3 \\ vorobelmariia@gmail.com, ${ }^{4}$ garmadijos@gmail.com
}

The purpose. To determine basic indexes of fermentation activity in dung of cows at mesophilic fermenting in anaerobic conditions (in vitro) at use of different biologically active specimens (BAS) and determination of efficiency of activation of methanogenesis processes. Methods. Chemical-analytical, mathematical-statistical. Results. Experimentally it is proved that biologically active specimens raise level of $\mathrm{CO}_{2}$ and $\mathrm{CH}_{4}$ in manure substratum. Liberation of these gases was more in comparison with control, accordingly in the Ist alternative on $15 \%$ (BAS $+\mathrm{Fe}^{+3}, \mathrm{Fe}^{+6}++$ glauconite), in the IInd - on 4\% (complex BAS with phosphoric joint in various densities of $\mathrm{P}_{200}, \mathrm{P}_{1000}$ ), the IIIrd - on 8\% (microbal specimen «Cellulose destructor» in dilution 1:500). Conclusions. Effective action is established of biologically active specimen which consists of $\mathrm{Fe}^{+3}, \mathrm{Fe}^{+6}$ and natural mineral of glauconite in dilution 1:200 - 1:1000 on basic indexes of fermentation activity of dung.

Key words: dung, cows, hotbed gases, methane, carbonic gas, biologically active specimen, methanogenesis process.

\section{https://doi.org/10.31073/agrovisnyk201806-08}

The main problem of today is the change of climate on the planet, which causes greenhouse gas emissions (carbon dioxide, methane, nitrous oxide, chlorine and fluorocarbon) as a result of the activity of industrial, agricultural energy objects [1-6]. Greenhouse gases causes not only to change of the temperature regime, but also to destruction of the ozone layer [3,4]. According to the last estimates by the Food and Agriculture Organization of the United Nations (FAO), greenhouse gas emissions in the agriculture, forestry and fish sectors increased practically twice the last 50 years and have a tendency to the further growth on $30 \%$ by 2050 y. [4]. Agriculture plays a considerable role in the global change of climate. Since it accounts for $10-12 \%$ of the total number of global anthropogenic emissions of greenhouse gases [2, 3, 5, 6].

The animal husbandry sector provides from 10 to $15 \%$ of all food calories and one fourth of part of the protein in the ration of man $[3,4,7]$, however, at the same time a animal husbandry is the main source of emissions of atmospheric ammonia and greenhouse gases $\left(\mathrm{CO}_{2}, \mathrm{CH}_{4}, \mathrm{~N}_{2} \mathrm{O}\right.$ etc.). It accounts for $9 \%$ of the total volume of $\mathrm{CO}_{2}$ emissions and $65 \%$ of $\mathrm{N}_{2} \mathrm{O}$, the potential of the latter in the process of global warming in 296 times higher the analogical parameters of carbon dioxide [4-8]. Except for that, the on animal husbandry sector accounts for $37 \%$ of all methane emissions, which is up to $20 \%$ of greenhouse gas content, but potential of influence on a climate in 23 times higher, than $\mathrm{CO}_{2}$ and this gas is able to accumulate in an atmosphere up to 12 years [5-8].

Since the influence of agricultural production on climate change becomes all more obvious, it is necessary to create the conditions to use the potential of agriculture in decreasing the consequences of the global warming. One of the priorities of addressing the issue of environmental protection is the recycling of animal waste by the method of anaerobic digestion into biogas.

The decomposition product of animal wastes under anaerobic conditions is accompanied by a release of methane and this process is called methane fermentation. In this complex of transformation involved a variety of microorganisms, the main of which are methane forming bacteria $[9,10]$.

The process of methane fermentation of manure can be divide into three stages (hydrolysis, oxidation and formation of methane) [10] or four stages of decomposition of the organic substrate [9], which are characterized in that the second stage (oxidation) in this case divided into two phases (phase oxidation and formation of acetic acid).

The special attention in researches on the above question indicated is accented on the increase of the effective anaerobic digestion of organic substances. Therefore, a search and development of preparations for the activating of fermentative processes in a manure are an actual task contemporaneity.

Materials and methods. The research was conducted in the laboratory of ecology of the Institute of agriculture of Carpathian region NAAS. Manure samples for determining the content of carbon dioxide $\left(\mathrm{CO}_{2}\right)$ 
and methane $\left(\mathrm{CH}_{4}\right)$ in the investigated substrate (in vitro) were taken from SE "EF «Obroshyne»" where the herd of Ukrainian black-and-white dairy cattle of the western intra-breed type is kept.

In each of variants weight of the investigated material was $300 \mathrm{~g}, 6 \mathrm{~g}$ - straw cut, length of stems of that did not exceed a $3 \mathrm{~cm}$.

Each variant of the experiment had a threefold repetition with the addition of $300 \mathrm{ml}$ of distilled water.

In the experiment, methane forming raw materials were presented in four variants: control - manure without the use of preparation, I - with the introduction of a biologically active preparation containing $\mathrm{Fe}^{+3}$; $\mathrm{Fe}^{+6}$ and natural mineral glauconite in dilution 1:200-1:1000, II - with the introduction of a complex BAP with a phosphoric compound of various concentrations P:200, P:1000, III - with the introduction of microbial preparation " Destructor of cellulose" in dilution 1: 500.

Determination of acidity in the manure mass was carried out using the instrument $\mathrm{pH}-\mathrm{Meter}$ Type N5170 (production of Poland).

The amount of $\mathrm{CO}_{2}$ in the manure substrate of cows (in vitro) was determined by the method of $\mathrm{N}$. Chibisova [11].

The content of methane in the investigated material was calculated mathematically, in the calculation that the yield of methane in manure of cattle is $65 \%$, carbon dioxide $-34 \%$ and up to $1 \%$ - other gases, including hydrogen sulfide to 0,1 .

Mathematical and statistical analysis results of the research was carried out using a standard statistical program package Microsoft EXCEL ta AtteStat.

Research results. An important factor in intensification the anaerobic digestion of biomass is maintaining the temperature regime and $\mathrm{pH}$ of the environment. The process of methanogenesis took place at the optimal indexes of fermentation in obedience to method V. Shatskyy, O. Sklyar, R. Sklyar [9].

In the process of realization of experiment on every stage of metagenesis in all variants at mesophilic fermentation in the investigated material a temperature regime was supported within the limits of $25-33^{\circ} \mathrm{C}$ and control the level of $\mathrm{pH}$ environment.

During the fermentation process in the control and in the studied variants, the $\mathrm{pH}$ was increased from 6,5 to 7,8 units.

Within 43 days, after the addition of preparations, a significant activation of fermentative activity in the manure mass was observed, the level pH increased from 7,8 to 10 units, as shown in fig. 1.

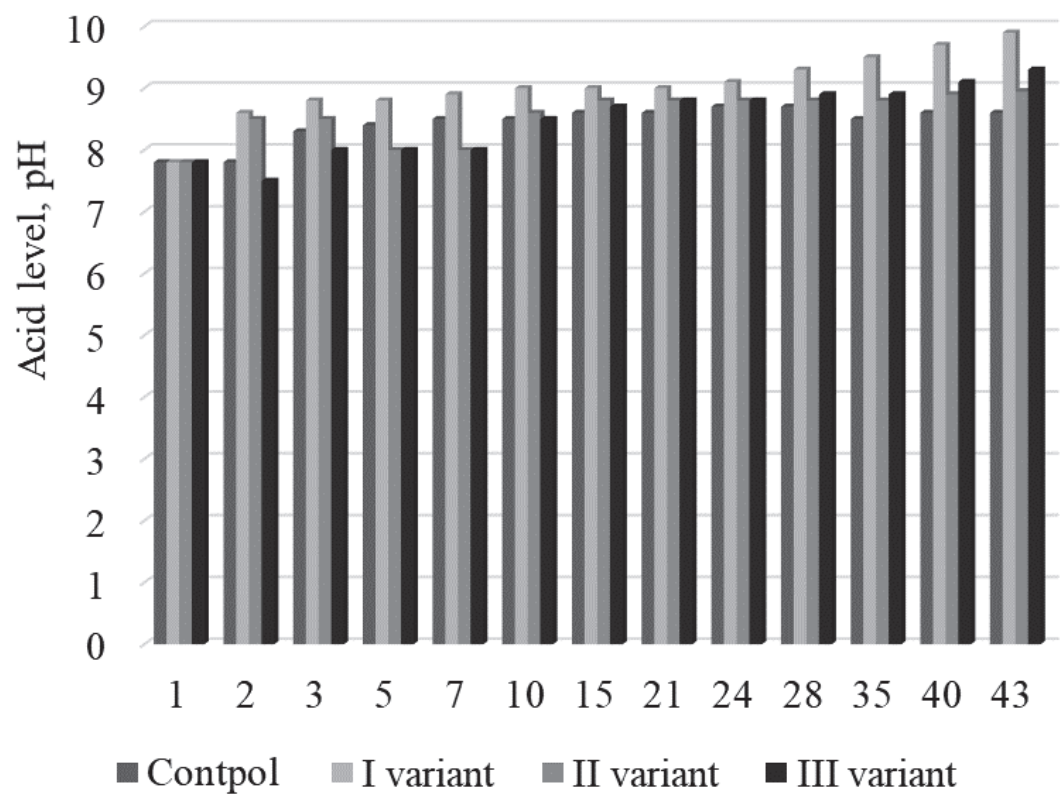

Fig. 1. - The level of acidity during the period flowing of the process of methanogenesis with the addition of BAP

Analyzing the results of experimental research, it was established that in studied variants, along with the increase of $\mathrm{pH}$ in the environment in the manure substrate, the content of carbon dioxide and methane is growing, as evidenced by the data obtained (see fig. 2, 3). 


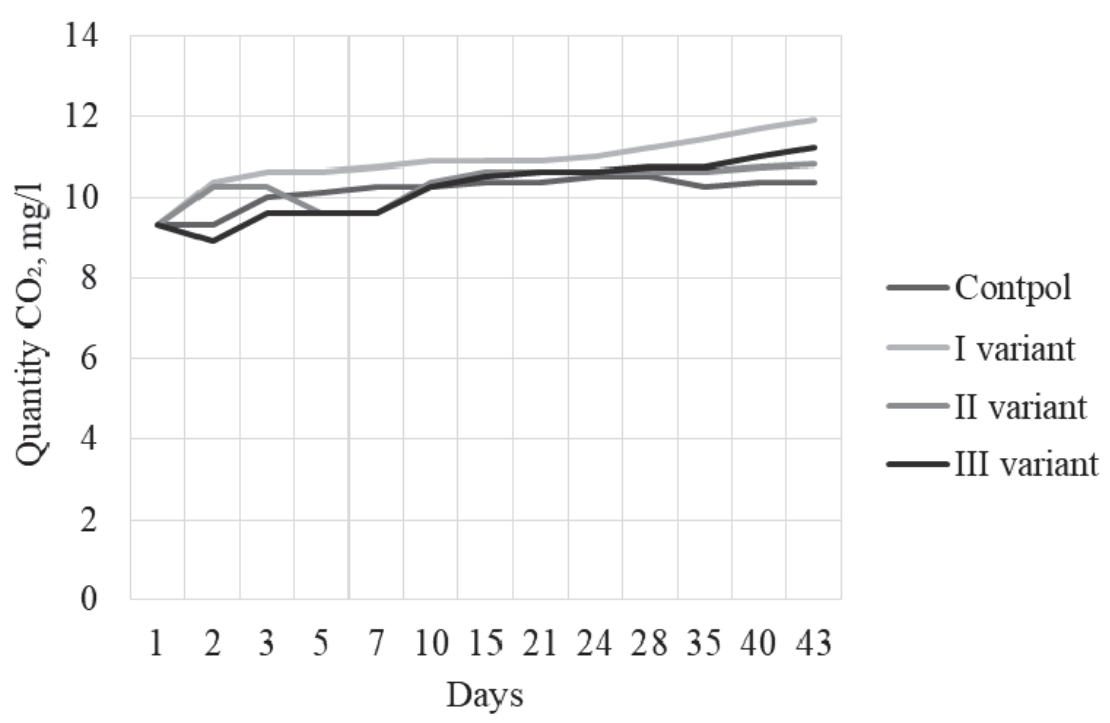

Fig. 2 - Number of selected carbon dioxide in variants with the introduction of BAP in the process of methanogenesis

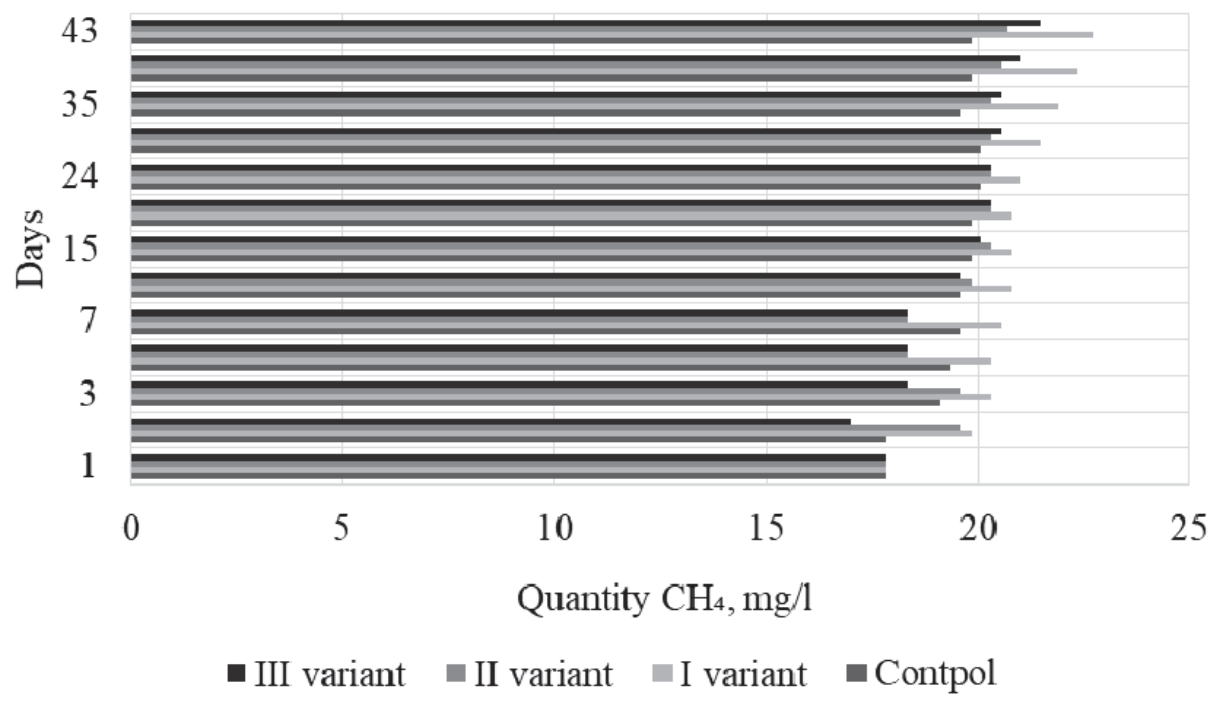

Fig. 3 - Number of selected methane in variants with the introduction of BAP in the process of methanogenesis

In variant I on the 43 day it was established that the level of allocation of $\mathrm{CO}_{2}$ and $\mathrm{CH}_{4}$ exceeds the control by $15 \%$. The use of a complex biologically active preparation with different concentrations of phosphorus (variant II) in the manure substrate increases the content of $\mathrm{CO}_{2}$ and $\mathrm{CH}_{4}$ by $4 \%$. It was established that the microbial preparation "Destructor of cellulose" (III variant) increases the yield of $\mathrm{CO}_{2}$ and $\mathrm{CH}_{4}$ by $8 \%$.

Thus, it was found that the complex BAP with $\mathrm{Fe}^{+3}, \mathrm{Fe}^{+6}$ and natural minerals glauconite in dilution 1:200-1:1000 is more effective on the level of carbon dioxide and methane selection in the manure substrate during mesophilic fermentation.

Consequently, the growth of the content of $\mathrm{CO}_{2}$ and $\mathrm{CH}_{4}$ in the application of the investigated complex BAP indicates the efficiency of their use for the activation of anaerobic fermentative activity and can be used to increase the allocation of methane in biogas plants.

\section{Conclusions.}

A more effective action on fermentative activity and processes of methanogenesis in cow manure (in vitro) has been found is a complex biologically active preparation that consisting of $\mathrm{Fe}^{+3}, \mathrm{Fe}^{+6}$ and glauconite in dilution 1:200-1:1000. The use of the above preparation in the manure substrate increases the amount of selected carbon dioxide and methane by $15 \%$. 
Prospects for further research in this area are the analysis of anaerobic fermentation of agricultural animal waste as an alternative source of energy and the solution of regional ecological problems of the agro-industrial complex. Establish the optimal ratio of biological and inorganic components for the decontamination of greenhouse gases in livestock wastes (in vitro, in vivo) and develop a way to reduce their emissions in the environment, as well as develop fermentative activation methods for methane selection for biogas plants.

\section{References.}

1. Kutsenko O.M., Pysarenko V.M. (1995). Ahroekolohiia. [Agroecology]. Kyiv: Urozhai, 256 p. [in Ukrainian].

2. Pinchuk V.O. (2015). Emisiia parnykovykh haziv u haluzi tvarynnytstva Ukrainy. [Emissions of greenhouse gases in the field of animal husbandry of Ukraine].Bioresursy i pryrodokorystuvannia. T. 7, № 1/2. P. 115-118. [in Ukrainian].

3. Khodorchuk V.la., Aliieva I.V., Martkoplishvili M.M. (2014). Minimizatsiia emisii parnykovykh haziv u silskomu hospodarstvi. [Minimization of greenhouse gas emissions in agriculture]. Ahrar. visn. Pivdnia. № 1. P. 168-173. [in Ukrainian].

4. Binkovska H.V., Shanina T.P. (2016). Otsinka obsiahiv vykydiv parnykovykh haziv u systemakh povodzhennia z silskohospodarskymy vidkhodamy Odeskoi oblasti. [Evaluation of greenhouse gas emissions in the systems of handling agricultural wastes in Odessa region]. Visn. KhNU imeni V.N. Karazina. V. 14. P. 91 97. [in Ukrainian].

5. Broucek J. (2014). Production of methane emissions from ruminant husbandry: A review. J. of Envi-ronmental Protection. V. 5. P. $1482-1493$.

6. Eckard R.J., Grainger C., de Klein C.A.M. (2010). Options for the abatement of methane and nitrous oxide from ruminant production: A review. Livestock Science. V. 130. P. $47-56$.

7. Khaliman I.O. (2013). Ekolohichni aspekty metanovoho brodinnia vidkhodiv tvarynnytstva. [Environmental aspects of methane fermentation of animal waste]. Visnyk Zaporizkoho natsionalnoho universytetutu. № 3. P. 168-172. [in Ukrainian].

8. Zhukorskyi O.M., Nykyforuk O.V., Bol-tyk N.P. (2015). Emisiia parnykovykh haziv vid koriv na fermakh iz vyrobnytstva moloka. [Greenhouse gas emissions from cows on farms milk production]. Visnyk ahrarnoi nauky. № 5. P. 45 - 48. [in Ukrainian].

9. Shatskyi V.V., Skliar O.H., Skliar R.V., Solodka O.O. (2013). Vplyv struktury substratu na vykhid biohazu pry metanovomu zbrodzhuvanni. [Influence of substrate structure on biogas output at methane fermentation]. Pr. TDATU. V. 13. T. 3. P. 3-12. [in Ukrainian].

10. Demchuk M.V., Reshetnyk A.O., Laiter-Moskaliuk S.V. (2010). Problemy utylizatsii hnoiu v suchasnomu tvarynnytstvi. [Problems of manure utilization in modern animal husbandry]. Nauk. visn. Lvivskoho natsionalnoho universytetutu veterynarnoi medytsyny ta biotekhnolohii imeni S.Z. Gzhytskoho. T. 12, № 3 (4). P. 188 - 195. [in Ukrainian].

11. Chibisova N.V. (1999). Praktikum po ekologicheskoj himii: uchebn. posobie. [Workshop on Environmental Chemistry: A Training Manual]. Kaliningrad. 94 p. [in Russian]. 